Article

\title{
Effective Teaching of Social Studies Concepts in Basic Schools in Ghana
}

\author{
Anthony Bordoh ${ }^{1,}{ }^{*}$, Francis Nyantakyi ${ }^{2}$, Alexander Kingsford Otoo ${ }^{3}$, Abena Boakyewa ${ }^{4}$, Philip Owusu-Ansah ${ }^{5}$ \\ Isaac Eshun ${ }^{1}$
}

How to cite this paper: Bordoh, A., Nyantakyi, F., Otoo, A. K.,

Boakyewa, A., Owusu-Ansah, P., \& Eshun, I. (2021). Effective Teaching of Social Studies Concepts in Basic Schools in Ghana. Universal Journal of Social Sciences and Humanities, 1(1), 46-53. Retrieved from https://www.scipublications.com/journal/index.php/ujssh/article/view/95

Received: July 29, 2021

Accepted: September 1, 2021

Published: September 2, 2021

Copyright: (c) 2021 by the authors. Submitted for possible open access publication under the terms and conditions of the Creative Commons Attribution (CC BY) license (http://creativecommons.org/licenses /by/4.0/).

\author{
${ }^{1}$ Department of Social Studies Education, University of Education, Winneba, Ghana \\ 2 Department of Arts and Social Sciences, St. Joseph's College of Education, Bechem, Ghana \\ ${ }^{3}$ Department of Social Sciences, Our Lady of Apostles College of Education, Cape Coast, Ghana \\ ${ }^{4}$ Department of Social Sciences, St. Louis College of Education, Kumasi, Ghana \\ ${ }^{5}$ Department of Social Sciences, St. Monica's College of Education, Ashanti-Mampong, Ghana \\ *Correspondence: bordohlity@yahoo.co.uk
}

\begin{abstract}
The study focused Effective teaching of Social Studies Concepts in Basic Schools in Ghana. The study adopted the descriptive survey design using quantitative approach. The population for the study consisted of all Social Studies teachers in the Junior High Schools (JHS) in the Tano South District. There were fifty-two Social Studies teachers at the JHS level in the district. Non-probability sampling technique (purposive and convenient sampling techniques) was used for the study. Purposive sampling technique was used to select all the fifty-two teachers and forty-one schools in the Tano South District. While the district was conveniently sampled for this study. The main instrument used to gather data was observation guide. The data gathered was analysed using the Statistical Product using Service Solutions (SPSS). The study concluded that, in respect to the teaching effectiveness of Social Studies teachers, the general performance in all the thematic areas assessed indicate that, Social Studies teachers are not at their optimum best in terms of planning and preparation, instructional skills, classroom management, communication skills and assessment skills. It is therefore recommended that, the Ministry of Education through the Ghana Education Service (GES) in collaboration with all the teacher training institutions training Social Studies teachers should fashion out teacher development programmes such as workshops and short courses for Social Studies teachers. In these programmes, the organisers must ensure that teachers have access to high quality content course work in Social Studies.
\end{abstract}

Keywords: Effective, Social Studies, Concepts, Basic Schools, Ghana

\section{Introduction}

Social Studies teachers teaching in the Junior High Schools in Ghana are in agreement that Social Studies is citizenship education. This is important because having a positive conception about Social Studies as a teacher is one sure way of making positive impact with regards to achieving the curriculum goals of the subject [1].

However, despite the varied schools of thought of what Social Studies is or ought to be, consensus has been built on citizenship education as the main goal of the subject, hence teachers should be trained to that effect, because pupils are trained towards the realization of the ultimate goal of education in Ghana, which is creating a well-balanced (intellectually, spiritually, emotionally and physically) individual with the requisite knowledge, skills, values and attitudes for self-actualization and for socio-economic and political transformation of the nation [2]. Social Studies has its goal which aims at helping 
the realization of the national goals. The enduring goals of Social Studies is the development of reflective, competent and concerned citizens [3]. Social Studies is therefore important in the school curriculum. In the context of Ghana, Social Studies is a citizenship education which aims at producing a reflective, competent, responsible, and participatory citizen [4].

Citizenship preparation and training is therefore the major pre-occupation of Social Studies since its inception. Social Studies originated from America in an attempt to find solution to social disharmony threatening the survival and integration of the youth due to social forces within the country and the concern and fear that Africa Americans and native Americans may not be able to fit into the society unless they understand the society and the forces thus operated within it and ways to recognize and respond to social power [5]. In addition is the fact that the reason for introducing Social Studies in Africa 1968 Mombasa conference was to use the subject as a tool in preparing citizens for the newly independent African states [5].

In Ghana the objectives of Social Studies at the Junior High School (JHS) according to Curriculum Research and Development Division are to;

- understand the interrelationships between the social and the physical environment and their impact on the development of Ghana

- appreciate the impact of history on current and future development efforts of the country.

- appreciate the various components of the environment and how these could be maintained to ensure sustainable development.

- recognize the major challenges facing Ghana and be able to develop basic knowledge and skills for dealing with such challenge.

- understand the dynamics of development in the world and their impact on development in Ghana.

- develop the knowledge, skills and attitudes needed for personal growth, peaceful coexistence, and respect for peoples of other nations.

- develop a sense of national consciousness and national identity [6].

It is therefore important to reflect and assess the competencies of Social Studies teachers because to attain the task of equipping students with the necessary competencies, skills and attitudes, the Social Studies teacher needs to possess certain pedagogical competencies that would enable him or her achieve the curriculum goals of the subject. Researchers defined three main components of pedagogical content knowledge to include the following themes:

- Knowledge of task

- Knowledge of students' prior knowledge

- Knowledge of instructional methods [7].

They measured pedagogical content knowledge by means of an assessment centre type of approach, in which teachers rated real life teaching scenarios in mathematics classes. The results showed that, teachers with more pedagogical content knowledge display a broader repertoire of teaching strategies for creating cognitively stimulating situations.

Pedagogical content knowledge is seen as the integrative results of three independent components. Subject matter mastery, pedagogical knowledge and knowledge of the teaching text [8]. Social studies teachers must therefore be equipped with knowledge of the problems contained in the syllabus and the various approaches (techniques and strategies) to help pupils to learn. Subject matter understanding strengthens the teacher's powers and in so doing heightens the possibilities of art of teaching [9]. Teachers' inadequate pedagogical competencies such as subject matter mastery, knowledge of instructional methods, and assessment techniques in Social Studies and the philosophy of teaching the subject are some of the factors said to be affecting the realization of the objectives of the subject [10,11-12]. Social Studies teachers should dedicate enough time for preparation of lesson plans, teaching learning materials and other related activities that will make the 
teaching of the subject effective and also impact on the attitude of learners positively. To achieve this, extensive reading is a prerequisite. Teachers must therefore dedicate enough time reading and to ensure adequate preparation, teachers need at least three basic reading materials (the syllabus/curriculum, textbook and the teacher's guide) to prepare for lessons [1]. The purpose of the study is to examine the effective manner of teaching and learning of Social Studies. The study sought to answer the following research questions (1) How effective are the social studies teachers in the Tano South District in the teaching of the subject?

\section{Materials and Methods}

The study adopted the descriptive survey design using quantitative approach. The population consisted of all Social Studies teachers in Ghana. The population for the study consisted of all Social Studies teachers in the Junior High Schools (JHS) in the Tano South District. There were fifty-two Social Studies teachers at the JHS level in the district. Nonprobability sampling technique (purposive and convenient sampling techniques) was used for the study. Purposive sampling technique was used to select all the fifty-two teachers and forty-one schools in the Tano South District. While the district was conveniently sampled for this study. The main instrument used to gather data was observation guide. The data gathered was analysed using the Statistical Product using Service Solutions (SPSS). The researchers coded each data for identification before scoring into frequency table and percentages. Data to answer research question was analysed. The individual respondents scores were summed up and calculated for percentages in ranges from very low, low, high, and very high. The data was based on a twenty-seven (27) item consists of four variables, namely, Planning and preparation; instructional skills; classroom management; and communicative skills and assessment.

\section{Results and Discussions on Teaching Effectiveness of Social Studies Teachers in Junior High Schools}

To find answer to the research question "how effective are the social studies teachers in the Tano South District in the teaching of the subject?" percentages were used. Also to establish a vivid evidence of the study, a close ended observation guide was designed to personally observe and assess how effective the Social Studies teachers in the Tano South District in the teaching of the subject. To achieve this, the observation guide was quantified and analysed using percentages and frequencies. The results on the first and second observation were merged together and average score was struck and summarized in ranges. The results are presented in Table 1.

Table 1. Results of observation of social studies teachers

\begin{tabular}{ccccc}
\hline Teaching effectiveness & Very low & Low & High & Very high \\
\hline Overall teaching effectiveness & $0(0 \%)$ & $14(70 \%)$ & $6(30 \%)$ & $0(0 \%)$ \\
\hline Planning and preparation & $0(0 \%)$ & $14(70 \%)$ & $6(30 \%)$ & $0(0 \%)$ \\
\hline Instructional skills & $0(0 \%)$ & $15(75 \%)$ & $5(25 \%)$ & $0(0 \%)$ \\
\hline Classroom management & $2(10 \%)$ & $14(70 \%)$ & $6(30 \%)$ & $0(0 \%)$ \\
\hline Communication skills & $2(10 \%)$ & $11(55 \%)$ & $6(30 \%)$ & $1(5 \%)$ \\
\hline Assessment & $2(10 \%)$ & $13(65 \%)$ & $5(25 \%)$ & $0(0 \%)$ \\
\hline
\end{tabular}


Table 1 provides details results on the two observations on the Social Studies teaching effectiveness. The overall performance indicates that most $(70 \%)$ of the respondents scored low. This observation gives the general impression that Social Studies teachers are not at their optimal best when it comes to the teaching of Social Studies. The teachers are not at their optimal best when planning and preparing their lessons. For example, my observation revealed that most Social Studies teachers in the district do not exhibits knowledge of subject matter when planning and preparing for their Social Studies lessons. The mean and standard deviation of $(\mathrm{M}=2.71, \mathrm{SD}=.456)$ gives that ample evidence (refer to appendix 1). With respect to whether Social Studies teachers make sure objectives are SMART and align instructional strategies with lesson objectives, the observation results give vivid indication that most teachers $(\mathrm{M}=2.36, \mathrm{SD}=.680)$ do not ensure objectives are SMART and align instructional strategies with lesson objectives. This was as a result of lack of reading and adequate preparation in that most of the lesson plans observed had only one reference material mostly the syllabus. This contributed to majority $(75 \%)$ of the teachers scoring low in the planning and preparation.

The findings contradict the outcome of a study conducted on "Exemplary university teachers: Knowledge and beliefs regarding effective teaching dimensions and strategies" published in The Journal of Higher Education found out that, exemplary teachers are highly organized, plan their lessons carefully, set unambiguous goals, and have high expectations of their students. Effective planning and preparation is a sine-qua-non in the whole business in the teaching enterprise [13].

Also, on the Instructional Skills results are not different with what was observed in the planning and preparation of their lessons. Since the teachers scored low (75\%). The apparent reason could be that when planning and preparation by the teachers are poorly done, it could lead to poor instructional performance. This finding was confirmed after analysing the individual items. Toughing on few of these items, it was observed that most teachers do not ensure that the content links with the objectives and challenges students' present knowledge, skills and values. Also, the results revealed that most teachers do not state purpose, objectives, and procedures for lessons. On the issue of whether teachers engage students in critical thinking and problem-solving, the result shows that most are not up to that task. Teachers were also identified not using techniques that modify and extend student learning. All these responses produced a mean and standard of $(\mathrm{M}=2.66$, $\mathrm{SD}=.478$ ) which is less than the test value 3.0 (refer to appendix 2).

Previous studies in Ghana and Nigeria are consistent with the finding above, for instance, a study on Social Studies teachers' competency needs for effective implementation of Universal Basic Education Programme in Nigeria concluded that most Social Studies teachers' are incompetent in the knowledge of the subject, content as well as in teaching including communication skills [14]. Also, a research conducted in Secondi - Takoradi on Social Studies teachers' content knowledge in Senior High Schools reveals that most teachers lack content knowledge in Social Studies [10]. This made them not able to understand the essence of the problems in the syllabus. As a result, could not select facts which would develop the civic competences of the learners. Similarly, a study on the topic transacting the social studies programme in Junior High Schools in the Obuasi Municipality in the Ashanti Region of Ghana concluded that majority of the teachers' paid little attention to most of the methods and strategies of teaching social studies.

With respect to their classroom management, the results show that most Tano South District do not use the Social Studies as one of the key and core subjects to manage the classroom environment. The low score of $70 \%$ was due to the fact that teachers did not give individual attention to pupils and also, the rapport between the teachers and the pupils were not the best. The individual item analysis attest to this worrying trend (refer to appendix 3). Contrary to the findings above, researchers emphasized that, clarity, stimulating students' interest, engaging and motivating students, enthusiasm, establishing rap- 
port with students, and maintaining positive classroom environment are effective practices of teaching [13]. This posit that, Social Studies teachers should be well versed in the rational and philosophy of the discipline to ensure effective teaching and learning in the classroom. A study also revealed that value of interest, motivating students to do their best, comfortable learning atmosphere, course organisation, effective communication, concern for student learning, and genuine respect for students were highly related to the criterion of teacher effectiveness [15]. Social Studies teachers' inability to manage their classroom effectively would have negative consequences in the performance of the students as well as their social life because the Social Studies classroom is a mirror of the society and as such whatever happens in the classroom has direct effect on the attitude of students who are the future of the Ghanaian society. Measures should therefore be put in place to improve the pedagogical skills of Social Studies teachers in the light of persistent contemporary quagmire the nation finds itself.

In relation to communication skills and assessment, the table presents similar results as to the other observational areas. The result shows that most teachers do not employ effective communication and assessment skills in the quest of their lesson delivery. The scores of $55 \%$ and $65 \%$ for communication and assessment skills respectively show that evidence.

For effective teaching to occur, effective communication is a prerequisite in lesson delivery [16]. Similarly, researchers alluded that, clarity and engagement are effective ingredients of effective communication [13]. Also, it is important to state that most teachers observed could not communicate the subject matter clearly and use effective persuasive massages that could bring change in attitude in learners (refer to appendix 4 for detailed item analysis). The fact that most teachers lack confidence and enthusiasm affected pupils. This could partly be blamed on ill preparation by the teachers.

With regard to the finding on assessment the study revealed that the low score of $65 \%$ indicating that majority of the teachers performed very low implying that teachers are not at their best when it comes to assessment. This was because most teachers neglected the affective domain which is the central focus in the profile dimension in the Social Studies curriculum and also, did not show much concern for pupils learning (refer to appendix 4) This finding confirms that, what exists in the classroom is consonant with the pedagogical requirements of the subject [12]. The study found out that, most Social Studies teachers did not assess the affective domain. Equally, a study on "JHS teachers' assessment in Social Studies" concluded that "assessment of higher levels of learning objectives and attitudes and values is neglected by teachers in their assessment practices" [12]. Social Studies aim at changing attitude of learners for the good of the society and therefore neglecting the affective domain in the assessment process will make it impossible to realise the curriculum objectives thereby affecting the overall development of the nation. Teachers must therefore ensure that assessment of all the areas outlined in the profile dimension contained in the Social Studies syllabus is done. It is important to state the refresher causes on assessment strategies for the Social Studies teacher should be done by all stakeholders

\section{Conclusions}

The study concluded that, in respect to the teaching effectiveness of Social Studies teachers, the general performance in all the thematic areas assessed indicate that, Social Studies teachers are not at their optimum best in terms of planning and preparation, instructional skills, classroom management, communication skills and assessment skills. The implication of the above finding is that when planning is poorly done, all the other activities in the classroom will likely be in disarray. Due to this Social Studies teachers will find it difficult to achieve the stated objectives in a lesson. 


\section{Recommendation}

It is therefore recommended that, the Ministry of Education through the Ghana Education Service (GES) in collaboration with all the teacher training institutions training Social Studies teachers should fashion out teacher development programmes such as workshops and short courses for Social Studies teachers. In these programmes, the organisers must ensure that teachers have access to high quality content course work in Social Studies.

Author Contributions: Conceptualization A. B; methodology, A. B and I. E; validation, A. B, F. N, A. K. O, Ab. B, P. O. A, I. E; formal analysis, A. B, F. N.; investigation, A. B, F. N, A. K. O, Ab. B, and P. O. A.; resources, A. K. O.; data curation, A. B, F. N, A. K. O, Ab. B, P. O. A. and I. E; writingoriginal draft preparation, A. B, F. N, A. K. O; writing-review and editing, A. B.; visualization, F. N, A. K. O, Ab. B, and P. O. A; supervision, A. B. and I. E; project administration, A. B, F. N, A. K. O, Ab. B, P. O. A. and I. E.; All authors have read and agreed to the published version of the manuscript.

Funding: "This research received no external funding"

Data Availability Statement: Data is available on request from the corresponding author.

Acknowledgments: we acknowledge the Dr. Anthony Bordoh for his input and suggestions

Conflicts of Interest: "The authors declare no conflict of interest." "No funders had any role in the design of the study; in the collection, analyses, or interpretation of data; in the writing of the manuscript, or in the decision to publish the results".

\section{Appendices}

Appendix 1. Analaysis of effectiveness of Social Studies teachers in the Tano South District in the teaching of the subject on Planning and Preparation

Test Value $=3.00$

\section{Planning and Preparation}

Mean

1. Exhibits knowledge of subject matter

2.37

\section{Overall Mean/SD}

Std. D .456 
Appendix 2. Analaysis of effectiveness of Social Studies teachers in the Tano South District in the teaching of the subject on Instructional Skills

\begin{tabular}{ccc}
\hline Instructional Skills & Mean & Std. D \\
\hline Content with objectives and challenges students' present knowledge, skills and & & \\
values. & 2.71 & .956 \\
State purpose, objectives, and procedures for Lessons & 2.36 & .680 \\
3. Give procedural and instructional directions clearly & 2.55 & .230 \\
and learning & 3.06 & .340 \\
4. Appropriate and timely introduction of TLMs & 2.37 & .457 \\
5. Due opportunity is given to pupils to ask questions. & 2.71 & .346 \\
6. Uses varied Motivational techniques on students & 2.36 & .540 \\
7. Relates lesson to prior knowledge and life Experiences & 3.05 & .540 \\
8. Presents lessons in a systematic manner & 2.34 & .670 \\
9. Uses effective questioning techniques of the level of students & 2.99 & .347 \\
10. Engages students in a critical thinking and problem-solving & 2.71 & .456 \\
11. Uses techniques that modify and extend student Learning & 3.36 & .230 \\
12. Engages students in lesson closure. & 2.05 & .430 \\
Overall Mean/SD & $\mathbf{2 . 6 6}$ & .478 \\
\hline Source: Field Data, 2017. N=50 & &
\end{tabular}

Appendix 3. Analaysis of effectiveness of Social Studies teachers in the Tano South District in the teaching of the subject on Classroom Management

\begin{tabular}{ccc}
\hline Classroom Management & Mean & Std. D \\
\hline 1. Manages classroom routines effectively & 2.56 & .530 \\
2. Respect diversity among students & 2.85 & .230 \\
3. Maintains positive rapport with students & 1.96 & .550 \\
4. Give attention to each pupil individually during Lessons & 2.97 & .437 \\
5. Knows each student by name & 2.76 &. .539 \\
Overall Mean/SD & $\mathbf{2 . 6 2}$ & $\mathbf{. 5 4 6}$ \\
\hline
\end{tabular}

Source: Field Data, $2017 . \quad \mathrm{N}=50$

Appendix 4. Analaysis of effectiveness of Social Studies teachers in the Tano South District in the teaching of the subject on Communication Skills and Assessment

\begin{tabular}{ccc}
\hline Communication Skills and Assessment & Mean & Std. D \\
\hline 1. Communicates with confidence and enthusiasm the subject matter clearly to pu- & 2.36 & .550 \\
pils. & 2.75 & .560 \\
2. Uses appropriate and accurate non-verbal, oral/sign and written communication & 3.06 & .837 \\
3. Project voice appropriately and timely & 2.88 & .576 \\
4. Monitors students' participation and progress & 2.99 & .830 \\
5. Provides immediate and constructive feedback & 2.85 & .430 \\
6. Bases assessment on instructional goals/objective & 2.96 & .650 \\
7. Teacher used appropriate question and based assessment on the profile dimension & & .437 \\
\hline in Social Studies. & $\mathbf{2 . 9 7}$ & .4 \\
\hline
\end{tabular}




\section{References}

[1] Nyantakyi, F., Bordoh, A., Anim, C., \& Brew, E. (2020). Social Studies Curriculum: Teachers' Conception and Efficacy Beliefs in Junior High Schools in Ghana.

[2] National Council for Curriculum and Assessment (NaCCA) Ministry of Education (2020). Social Studies Curriculum for B7- B10. Ghana

[3] Martorella, P. (2001). Teaching social studies in middle and secondary schools (3 ${ }^{\text {rd }}$ ed.). Prentice-Hall.

[4] Blege, W. (2001). Social studies: Theory and practice. Wallyblege Publications.

[5] Tabachnik, B. R. (1991). Social studies in elementary school programmes. In A. Lewi (Ed.). The international encyclopedia of curriculum. Pergamon Press.

[6] CRDD (2007). Social studies teaching syllabus for junior high schools. Ministry of Education

[7] Krauss, S., Brunner, M., Kunter, M., Baumert, J., Blum, W., Neubrand, M. \& Jordan, A. (2008). Pedagogical content knowledge and content knowledge of secondary mathematics teachers. Journal of Educational Psychology, 100(3), 716-725

[8] Gess-Newsome, J., \& Lederman N.G. (eds.) (1999). Examining pedagogical content Knowledge. Kluwer.

[9] Scheffler, I. (1973). Reason and teaching. Bobbs-Merrill.

[10] Bordoh, A., Eshun, I., Bassaw, T. K., Kwarteng, A. Y. (2015). Social studies teachers' content knowledge in senior high schools in the Secondi-Takoradi Metropolis in the Western Region of Ghana. American Journal of Social Science Research, 1(3), 169-177.

[11] Kankam, B. (2013). Teachers' perception of the importance of teaching citizenship education to primary school children in Cape Coast, Ghana. Journal of Arts and Humanities, 2(2).

[12] Ngaaso, C. K. (2015). Assessing junior high school teachers' assessment in social studies: An objective based approach. The Social Educator, 4(3)

[13] Hativa, N., Barak, R., \& Simhi, E. (2001). Exemplary university teachers: Knowledge and beliefs regarding effective teaching dimensions and strategies. The Journal of Higher Education, 72(6), 699-729.

[14] Ogheneakoke, E. C. (2013). Social studies teachers' competency needs for effective implementation of Universal Basic Education (UBE) Programme in Nigeria. Nigeria Journal of Social Studies and Civic Education, 3 (1), 21-28.

[15] Adu-Yeboah, C. (2008). Transacting the Social Studies Programme in Junior High Schools in the Obuasi Municipality in the Ashanti Region of Ghana. Published Thesis Submitted to the Department of Basic Education of the Faculty of Education, University of Cape Coast in Partial Fulfilment of the requirements for the Award of Master of Philosophy Degree in Basic Education.

[16] Young, S., \& Shaw, D. G. (1999). Profiles of effective college and university teachers. The Journal of Higher Education, 72(6): 699729. 